\title{
Language and status: On the limits of language planning
}

\author{
Lloyd Hill ${ }^{1}$ \\ Department of Sociology and Social Anthropology, Stellenbosch University, Private Bag X1, 7602 Matieland, \\ South Africa \\ Email: 1loydhill@sun.ac.za
}

\begin{abstract}
'Language status' is a concept that has been central to South African language policy debates since the early days of the negotiated transition, which culminated in the 1996 Constitutional commitment to developing eleven official languages. This constitutional commitment has not however been translated into a concrete legislative and administrative agenda. Recent critiques of language policy have attributed this 'policy gap' to problems associated with policy implementation. In this article I argue that policy difficulties can equally be attributed to theoretical problems associated with the concept of 'language status', which have their origins in a broader international discourse on language planning. This article is therefore presents a sociological critique of 'language planning', based on a conceptual analysis of key terms that underpin the current debate on language policy: principally 'language', 'language planning' and 'status.'
\end{abstract}

Keywords: Language politics, language policy, language planning, corpus planning, status planning

\section{Introduction}

"A language is a dialect with an army and a navy." ${ }^{2}$ This well known comment - attributed to Max Weinreich in 1945 - marked the beginning of a new era in the study of language in society. Weinreich's controversial assertion about the historical significance of political conflict in language standardisation also hints at a crucial ontological issue in debates on the meaning of language: to what extent can the status attributed to a language be distinguished from the status associated with those who speak it?

'Language status' is a concept that has been central to South African language policy debates since the early 1990s. In a very general sense the term resonates with numerous rightsorientated discourses that have emerged during the transition from apartheid to constitutional democracy. To the extent that language status has been established as a legal construct, this development traces its origins to academic debates on language standardisation, the relative status of South African languages and the extent to which "lower status" languages can - and should - be planned and developed.

In this article I explore the concept of 'language status' within the context of the wider debate on language policy and planning. In post-1994 South Africa the term 'language planning' has been used to refer to both a component of a language policy process (whether at national, 
regional or institutional level) and academic deliberations on this process. In recent years the South African discourse on language planning has become increasingly focused on a perceived gap between the stated objectives of formal language policy and actual language practices. To the extent that one may speak of a 'policy gap', this is particularly evident with respect to what is termed 'status planning'. While there are no doubt problems with the implementation of language policy, this formulation assumes the availability of a coherent national policy to implement. A recent High Court judgment has - ironically - both highlighted the lack of policy and reinforced the perception that current language policy problems are essentially matters of implementation. ${ }^{3}$ They are not.

I argue that the difficulties associated with language planning were aggravated by an overly programmatic approach to language policy development on the part of language academics and activists in the immediate aftermath of 1994 . This policy response can in turn be traced to a problematic conception of language and language status in much of the domestic and international literature on language planning. The present article therefore focuses specifically on a conceptual and theoretical analysis of key terms that have underpinned the development of language policies (at various levels) since 1994. The analysis that follows is partly inspired by Raymond Williams' (1983) influential book, Keywords - a vocabulary of culture and society, and by two similar South African volumes (Boonzaier and Sharp 1988; Shepherd and Robins 2008). While Williams' book has an entry on dialect, language concepts are conspicuously absent in both of the South African books.

The article begins with a brief discussion of the relatively recent South African debate on multilingual language planning. The conceptual difficulties associated with language planning are traced to the post-World War 2 emergence of 'language planning' as a specialized field within American applied linguistics. In this tradition a distinction between 'corpus planning' and 'status planning' is the lynchpin of a technicist policy discourse that tends to abstract language planning away from the conflict and more subtle forms of contestation that invariably accompany the selection of a language in any given domain. At the heart of the problem is the conceptualisation of status as a property considered external to the definition of a language. I therefore present a case for treating status and social stratification as constitutive processes in the construction of relatively discrete language groups and conclude with a brief statement of the policy implications that follow from this approach.

\section{Post-1994 language planning: the rise of a new policy discourse}

'Language status' emerged as a core concept in an official discourse on language planning during negotiated transition of the early 1990s. During these negotiations, which culminated in the 1993 interim constitution, language status was one of the last issues to be formally addressed. In an eleventh hour compromise (Heugh 2002; Beukes 2008) between the incumbent National Party and its main negotiating partner, the African National Congress, the question of official status was resolved by means of a "non-diminution" clause in the interim constitution, in terms of which the traditional status and rights enjoyed by languages in the previous dispensation would remain unaffected by the commitment to extend rights and status to languages that had previously been "restricted to certain regions". ${ }^{4}$ In the 1996 constitution the clause granting official status to eleven languages ${ }^{5}$ is followed by one that recognizes "the historically diminished use and status of the indigenous languages of our people" and commits the state to take "practical and positive measures to elevate the status and advance the use of these languages." 
The 1993 and 1996 constitutional provisions on language constitute two influential early statements in a growing domestic discourse on multilingual language planning. This new literature can be traced back to two relatively distinct concerns about language, which began to converge during the 1980s. The first was a concern for the future status of Afrikaans in post-transition Namibia and South Africa. The second was a concern to develop the indigenous African languages and thereby render them capable of serving as viable media of instruction in primary and secondary education. An international literature on language planning therefore provided a means of integrating two very different language agendas. For Afrikaans speakers the concern was that Afrikaans would lose status, which is to say lose many of the higher functions with which it had traditionally been associated (Combrink 1991; Cluver 1992). Principal among these was its status as a medium of instruction in higher education. Among advocates of African language development the concern was for higher functions that have yet to be developed. Thus Mutasa (1999:86) argues that "[no] one seems to take African languages seriously. They seem to have nothing to offer except everyday communication between members of families." In response to concerns such as this, Webb (2002:26) argues that "[a] major programme of language revalorisation is clearly necessary."

Post-1994 policy on language planning therefore represents a synthesis of these two status concerns and academics have played a significant role in forging this synthesis. Language specialists have been particularly influential in this process: while Afrikaans language professionals were particularly influential during the 1990s, language planning in South Africa is now a predominantly English medium policy discourse in which English and African language specialists play an increasingly prominent role. Ironically, the official commitment to multilingualism and the associated development of a domestic discourse on multilingual language planning has coincided with the de facto growth in the status of English. Thus Heugh (2002:461) comments that the "use of English became apparent in virtually all government work." Similarly, Kamwangamalu (2002:16) cites press reports to argue that "the new language policy is not working for all languages in post-apartheid South Africa; and that the tides seem to be turning increasingly in favour of English." It is generally accepted that the status of English has grown significantly during the last sixteen years. Moreover, this new status has come largely at the expense of the public status of Afrikaans, which nevertheless retains considerable status in most formal sectors of the economy. ${ }^{7}$ Beyond formal recognition at national and regional level, the nine official African languages have not recorded significant changes in actual patterns of use and have actually declined in some formal domains - and notably in formal language teaching (Beukes 2008:3). The most noteworthy exception to this trend is the increase in the circulation of isiZulu newspapers. ${ }^{8}$

For reasons discussed below, the historical development (and recent decline) of Afrikaans as a formal public sector language has provided particular impetus to the development of a domestic literature on language planning. Thus, Kamwangamalu (cited in Ridge 2001:28) argues that "during apartheid Afrikaans was developed and used successfully as a means of determining access to political power and economic resources. The same policy could work equally for African languages." Ridge (2001:28) questions whether this would work "equally for African languages", but argues that this proposal "signals the importance for language planning of institutionalising status." To what extent can this generic concern to institutionalise (multilingual) language status be explained in terms of the specific status concerns of Afrikaans speakers? There are at least two influential factors that do relate to the current socio-economic positioning of (predominantly white) Afrikaans speakers. The first is the extent to which Afrikaans speakers constitute the most powerful language movement in 
the country. ${ }^{9}$ The second relates the concentration within the Afrikaans-speaking community of more generic language skills associated with language planning. Unlike South African English, Afrikaans is an indigenously standardised language, and for this reason Afrikaans language professionals tend to have most of the key skills associated with language standardisation, notably lexicographic and other competencies associated with corpus planning. Thus the Woordeboek van die Afrikaans Taal (WAT or Dictionary of the Afrikaans Language) - based in Stellenbosch - has been instrumental in establishing dictionary units for the official African languages. ${ }^{10}$

To explain the rapid growth of a domestic discourse on language planning principally in terms of 'neo-Afrikaner nationalism' or language activism would however be a gross simplification. To do so would discount the significance of two additional ideological factors: the influence of a relatively small but growing corps of African language professionals and language activists; and the salience of Afrikaans and South African multilingualism within an influential and predominantly Anglophone international literature on language planning. The formal situation of a South African approach to language planning within a wider academic field is evident in the final report (see excerpt below) of the Language Plan Task Group (Langtag), the official body tasked with drafting a national language plan:

[Viewed] from the perspective of language planning as a discipline within the field of applied linguistics and as a conscious practice, the LANGTAG process, short as it has been, is indeed one of the more significant developments in the second half of the $20^{\text {th }}$ century. ${ }^{11}$

This international discourse accounts for key contours of the domestic debate - notably the tendency to understand language planning in terms of "two related but distinct types of activities: status planning and corpus planning" (Reagan 2002:420). This distinction is drawn from a growing international literature on language planning, which numerous South African authors have drawn on in contrasting ways (Pieterse 1991; Webb 1996b; Moodley 2000; Wright 2000; Alexander 2002; Reagan 2002; Webb 2002; Beukes 2008).

The South African debate has therefore imported a number of fundamental fault lines from the international literature on language planning. More generally, the conceptual problems evident within this wider literature have their roots in a form of post-World War 2 institutionalized amnesia: the systematic bracketing of the conflicts associated with the prewar formalization of languages and the non-scientific language planning activities of nationalist movements, great writers, colonial administrators and missionaries. As a subdiscipline within linguistics, language planning is therefore a relatively recent episode within a much longer history of attempts to standardize language. More specifically, as a specialized academic field language planning constitutes an attempt to appropriate, formalize and apply the fraught history of language standardization. This process is explored in the following section, which focuses particular attention on the founding distinction between 'corpus' and 'status planning.' While the tendency towards the selective appropriation of history has deeper roots and is to some extent the raison d'etre of any language industry, this particular manifestation is intimately related to the rise of English as a global medium of communication. Formal language planning therefore needs to be situated clearly within a wider context: the longue durée of language identification, legitimation and standardization. 


\section{Language planning and the externalization of status}

To the extent that there is a discernable history of language standardization, the key question is to what extent this has been an orchestrated or historically contingent process. Can languages be planned? And to the extent that planning has played a role in the standardization of national languages, can/should this process be distilled to form the basis of an applied science?

The emergence of language planning as an applied field of study can be attributed to a number of developments in the post-World War 2 period. The first and most obvious of these was the rise of the United States to a position of political, economic and intellectual preeminence. Language planning emerged as a predominantly American discourse, which coincided with the growth of American sociolinguistics as a distinct sub-discipline of linguistics. Secondly, decolonization and the creation of independent states in Africa and Asia constituted a new and very different market for language expertise. These new markets put pressure on the relatively new discipline of linguistics, which had hitherto been grounded in the comparative study of Indo-European languages. "Sociolinguistics", "linguistic anthropology" and the "sociology of language" are terms that emerged in the aftermath of World War 2. The designation of new language subfields during this period reflected the emergence of new epistemic space between the social sciences and an increasingly autonomous field of linguistics. This epistemic shift is reflected in the phrases "language in society", "language and culture" and "languages in contact", all of which reflect a concern for the contextual and relational aspects of language.

A particular combination of descriptive and prescriptive concerns set these new subdisciplines apart from the more traditional descriptive tradition in general linguistics. During the 1950s the descriptive focus shifted to the developing world, where attempts to describe and enumerate languages and dialects proved to be particularly difficult. To this new normative orientation language planning added an explicit political agenda: the need to make value judgments and formulate policy statements based on an accurate description of the context.

Language planning therefore emerged as an applied field of sociolinguistics - broadly defined to include the other sub-disciplinary orientations referred to above - and as such reflects two general orientations of the sub-discipline: a normative concern for 'small' languages and the contextual study of linguistic diversity; and a theoretical shift from abstract structural to functional explanations of language in society. Moving beyond the traditional linguistic description of the structure of a language (langue) - abstracted away from actual utterances or parole - sociolinguists began to focus more on function, which is to say on the description of linguistic diversity in terms of categories of use (registers) and the hierarchical arrangement of (more or less prestigious) uses (Halliday 2007:251).

Language planning therefore emerges within the context of a growing sociolinguistic orientation to the general study of languages in contact ${ }^{12}$ and the more focused study of the language problems of developing nations. ${ }^{13}$ The political context of this new academic trend was post-1945 'nation building' (Fishman 1968:54) and the emergence of new nationalist movements in recently decolonized states. These new states constituted a ready market for new ideas on language use and development. Language planners sought to promote the development of minority languages through the agency of the state ${ }^{14}$ and societal institutions, 
or in other words, through a process of language policy formation and implementation. Fishman describes this new sociolinguistic interest as a "rapidly expanding concern with the language problems of disadvantaged speakers of non-standard varieties" (Fishman 1968:12). Decolonization in Asia and Africa and the rise of 'new' nations and new nationalist movements therefore provided the main political impetus to the development of a new applied science. Consider in this regard the following comment:

Here was an opportunity for sociolinguists to see their scientific endeavours translated into hard political decisions, and to have their work sponsored by state governments and international organizations.

(Blommaert 1996:1)

The inspiration for a sociologically orientated approach to language planning came by way of Francophone studies of North Africa. The French term 'diglossie' was introduced by the Arabic scholar William Marçais in 1930, but only achieved widespread prominence after it was calqued into English by Charles Ferguson in 1959. Ferguson used the term 'diglossia' to denote a situation where two varieties of the same language in a particular speech community are used contemporaneously in definite but non-overlapping roles. Ferguson (1959:327) restricted his use of the term to four cases: Egypt (Classical Arabic - Egyptian), Switzerland (German - Swiss German), Greece (katharévusa - dhimotiki) and Haiti (French - Haitian Creole). He did however speculate on the wider potential application of the term (notably in China). The term 'diglossia' was introduced into a context in which 'bilingualism' had traditionally been used as a psychological construct. In the hands of Ferguson and Fishman (see Ferguson 1959; Fishman 1967; and Fishman et al 1968) diglossia comes to be associated with a kind of societal bilingualism, a sociological construct to the extent that bilingualism now refers to a functional division of labour within a language community. ${ }^{15}$

Over and above this conceptual shift, Fishman was instrumental in the development of a macro-sociological approach to language planning. This orientation is implicit in his extension of the meaning of 'diglossia' to cover the functional relationship between unrelated languages, notably in post-colonial states, where the super-ordinate language tends to be a European language. This macro-orientation to language planning was stimulated by an analysis of "cross-polity files", i.e. state-level statistical data on minority languages, which were increasingly available during the 1950s and 1960s (Fishman 1968:54).

Notwithstanding Fishman's efforts to draw in sociologists and political scientists, language planning has emerged as an applied field situated within linguistics. The reason for this can be traced to core assumptions about the nature of the enterprise, which Fishman shares with a number of other influential early contributors to the field. Language planning constitutes a form of applied linguistics, to the extent that it has been conceptualised as an essentially synchronic project, which is concerned with: (1) isolating key features in the historical development of relatively advanced 'standard' languages; (2) modelling the processes that these languages went through; and (3) using these models as the basis for policy intervention on behalf of weaker language communities.

Language planning theory is founded on Kloss' (1969) distinction between corpus planning and status planning. Corpus planning is defined as the internal development of a language (grammar, lexicon etc), while status planning involves the external or functional development of a language in a society. Here the term 'status' is commonly used as a synonym for function. ${ }^{16}$ Subsequently, others have expanded this model to include additional dimensions, 
such as 'acquisition planning' (promoting and spreading language learning) and 'prestige planning' (creating favourable psychological background for long-term planning), but these are clearly elaborations on the broad concept of 'function.' This basic distinction was then elaborated by Haugen $(1983,1997)$, to form the following model of language planning, summarized in Table 1.

Table 1. Haugen's model of language planning

\begin{tabular}{|l|l|l|}
\hline $\begin{array}{l}\text { Society } \\
\text { (external) functional change }\end{array}$ & \multicolumn{1}{|c|}{ Norm / Structure } & \multicolumn{1}{c|}{ Status / Function } \\
\hline $\begin{array}{l}\text { Language } \\
\text { (internal) language change }\end{array}$ & 2. Codification & 3. Implementation / acceptance \\
\hline
\end{tabular}

Haugen's fourfold model of language planning (summarised in Table 1) depicted the process in terms of the following stages or processes.

- $\quad$ Selection of a 'norm' speech variety for the purpose of codification

- Codification of a standardized code or written norm, which involves graphisation (developing a writing system), grammatication (establishing rules or norms of grammar) and lexicalization (specifying or developing vocabulary)

- Implementation, or the socio-political realization of decisions made regarding selection and codification

- Elaboration or modernization, i.e. terminological and stylistic development of a codified language.

This model has proved to be very influential and has underpinned numerous studies in different parts of the world. ${ }^{17}$ Language planning had its heyday during the 1960 s and the 1970s. Enthusiasm subsequently waned, as political and economic crises deepened in many parts of the developing world. Blommaert noted the recent renewal of interest and attributes this in part to South Africa's attempts to institutionalise multilingualism (Blommaert 1996:2). Another reason is the fact that the field is no longer predominantly concerned with the developing world. The numerous trends associated with globalization have shifted the focus to the developed nations of Europe and North America. In Europe in particular, the presumed national consensus on language has in numerous states been challenged by two growing phenomena: transnational migration and sub-nationalism. This has, to a considerable extent, shifted the academic emphasis from national planning to the contrasting language rights claims of autochthonous (territorial) and allochthonous (immigrant) minorities (Wright 2004).

The fundamental problem with language planning projects formulated in this way is conceptual. The distinction between 'corpus planning' and 'status planning' facilitates the creation of an ostensibly neutral applied science, but to the extent that this science has been built around the technical activities associated with corpus planning, status planning is reduced to a residual category. The conceptual problem at the heart of language planning may therefore be rephrased as a tendency to externalise status; or a tendency to airbrush the history of social contestation and political conflict out of language standardisation. More fundamentally, this tendency is related to the manner in which status tends to be theorised as an extraneous variable or factor considered external to the process of identifying languages and dialects. 


\section{Dialect and the stratification of languages}

The relationship between language and dialect is a touchstone issue in the historical development of the modern language disciplines. An exploration of this relationship is pivotal to a historical account of language standardization. 'Dialect' was a Renaissance import from Ancient Greek: the word appears in English in 1579, about 15 years after it first appeared in French (Haugen 1966:922). The significance of these dates relates to their situation approximately a hundred years after the emergence of printing as a socially significant phenomenon. ${ }^{18}$ The new writing technology presented the first generation of printerpublishers with a dilemma: which spoken language to use as a basis for printing? This dilemma is articulated as follows in one of the first books published in English:

And that comyn englysshe that is spoken in one shyre varyeth from a nother. In so moche that in my dayes happened that certayn marchauntes were in a shippe in tamyse for to haue sayled ouer the see into zelande/ and for lacke of wynde thei taryed atte Forlond. and wente to lande for to refreshe them And one of theym named sheffelde a mercer cam in to an hows and axed for mete. and specyally he axyed after eggys And the goode wyf answered. that she coude speke no frenshe. And the marchaunt was angry. for he also coude speke no frenshe. But wolde haue hadde egges/ and she vunderstode hym not/ And thenne at laste another sayd that he wolde haue eyren/ then the good wyf sayd that she vnderstod hym wel/ Loo what sholde a man in thyse dayes now wryte. egges or eyren/ certaynly it is hard to playse every man/ by cause of dyuersite and change of language. ${ }^{19}$

(Caxton in Bühler 1960:27)

The writer is William Caxton, the first English printer, and the extract provides an interesting early reflection on the problems associated with the creation of a standardized print-language. If languages are constantly changing, how is it possible for the print-medium to continue to reflect a spoken form of the language? The short answer is that it is not possible: printing establishes a written standard and printing has had a profound effect on the subsequent development of spoken languages.

The importation of the word 'dialect' from Greek into numerous European languages therefore formed part the gradual evolution of a response to this dilemma. Haugen (1966) notes that during the classical period of Ancient Greece there was no unified Greek language norm. While dialects in this context bore the names of Greek regions, they were also functionally specific written norms associated with specialized literary uses (e.g. Ionic for history and Attic for tragedy). During the post-classical period these dialects were eventually replaced by a unified norm, the Koiné, which was essentially the dialect of Athens. 'Dialect' therefore enters French, English and other emerging 'print-languages' ${ }^{20}$ as part of a broader social process: the analogical transfer of Ancient Greek experience as a means of (1) explaining the emergence of new print standards in sixteenth century Europe; and (2) legitimating the assertion of new written and spoken norms that during the nineteenth century would come to be known as national languages. Key aspects of this process are evident in the English senses associated with the word.

References to 'dialect' in English tend to be divided into two broad senses: (i) a "manner of speech peculiar to, or characteristic of, a particular person or class"; and (ii) one of the "subordinate forms or varieties of a language arising from local peculiarities of vocabulary, pronunciation, and idiom" (OED, 2010). This latter sense includes "a variety of speech 
differing from the standard or literary 'language"'"21 (OED, 2010). In these senses we can see the roots of the contemporary linguistic distinction between descriptive and prescriptive approaches to language. ${ }^{22}$ Sense (i) conveys a basic recognition of difference, which may or may not overlap with sense (ii), in which a norm forms the basis of a distinction between subordinate and superordinate forms. What is at issue here - to adapt Williams (1983:105) is not the "evident fact that ways of speaking differ", but rather the processes associated with the sub-/superordination of relatively distinct language forms. Williams argues that it is within the centralizing process of language standardization - a process of cultural domination - that "wholly native, authentic and longstanding variations become designated as culturally subordinate." But how longstanding and discrete were these 'native variations' before the invention of printing? ${ }^{23}$

The centralizing process to which Williams refers incorporated numerous processes associated with the rise of modern state-based political economies. 'Dialect' was therefore not simply imported into European languages in the sixteenth century; it formed part of a complex set of social processes - associated with the rise of European state- and nationbuilding - that would eventually produce both standardized languages and regional subdivisions. As Bourdieu notes, a standardized language should therefore not be thought of as a mere selection from a crop of pre-existing regional dialects:

Only by transposing the representation of the national language is one led to think that regional dialects exist, themselves divided into sub-dialects - an idea flatly contradicted by the study of dialectics [...] And it is no accident that nationalism almost always succumbs to this illusion since, once it triumphs, it inevitably reproduces the process of unification whose effects it denounced (Bourdieu 1991:46).

Bourdieu notes that, in the absence of objectification in writing, languages exist only in a "practical state" (Bourdieu 1991:46). 'Dialect' therefore enters the lexicon at a time when new practices associated with printing and reading are beginning to acquire new forms of social distinction - a process that would subsequently give rise to popular and literary forms of 'a language.' And when it became desirable to gloss one in terms of the other, this early form of language stratification was manifested most significantly in the form of the monolingual dictionary. ${ }^{24}$ The spread of printing and the gradual emergence of new economies of print therefore gave rise to radical new processes of objectification: the development of a written norm by means of the promotion of mass literacy "which enables the written norm to exercise an influence on the vernacular, while at the same time fostering the ideal that the written language should be a faithful mapping of it" (Coulmas 1992:37). This is, of course, far from a neutral or uniform process, for language standardization is invariably associated with a political project, namely linguistic nationalism. The nineteenth century was the heyday of both linguistic nationalism and language standardization: following the industrial revolution, state-based print markets formed the basis of powerful new political economies, in which the ideologies that underpinned both nationalism and imperial expansion were also instrumental in establishing powerful new 'national' and 'international' languages.

It is therefore difficult to dissociate language standardization from the chequered political history of any given standardized language. In the South African context, for example, it is not possible to understand the emergence of English as the dominant standard language without referring to the history of the Cape and Natal colonies, Milner's Anglicization policies, the socioeconomic position of white English speakers and their deference to cultural 
norms emanating from Britain and the United States. Similarly, Afrikaans as an alternative standard cannot be understood in isolation from Afrikaner nationalism and the racial motivations associated with 'ausbau' or the abstraction of a standard from a Dutch creole continuum.

Like national histories, a history of any given 'standard' language will therefore be a contentious and contested endeavor. And one, moreover, that does not easily lend itself to language policy and planning activities. By contrast, histories of dialects are difficult to write, as they often involve the reification or denial - through the medium of a written standard - of a tacit sense of linguistic positioning within a stratified social structure. This was the dilemma that nineteenth century missionaries faced in their efforts to codify the speech of their adherents. As Harries (2007:168) notes, with reference to "Thonga" (Xitsonga), the protolinguistic activities of the missionaries produced simultaneously both the standard language and its subordinate dialects.

While Thonga was the product of the mission, the subordinate dialects and patois were linked to the chiefs and headmen who, with few exceptions, presented a major barrier to evangelization.

(Harries 2007:167)

Perhaps it is a reluctance to recognize historical continuity with this period that explains why dialect tends to be the stepchild in the conceptual repertoire of modern linguistics. While some linguists use it, many more tend to be wary of its normative association with 'nonstandard' language and the negative connotation ${ }^{25}$ that it frequently carries in common sense usage. On the one hand this reluctance reflects sensitivity to the spatial complexity of modern language forms. Dialect has an additional sense of "a particular language in relation to the family of languages to which it belongs" (OED, 2010). This remains a relatively specialised sense, which gained currency following the late nineteenth century emergence of dialectology as a specialised field of study. ${ }^{26}$ To the extent that the term comes to be associated with language forms above and below the national language, it played a significant role in fostering a new sense of scale and functional scope in language. ${ }^{27}$ Hence the distinction between 'dialect' (regional or social) as a "variety according to the user" and 'register' as "a variety according to use" (Halliday 2007:251). In accordance with this sensitivity, 'variety' is often preferred as the generic term.

On the other hand, the reluctant use of 'dialect' tends to reflect a scientific disposition associated with the rise of an autonomous discipline (linguistics) concerned with the descriptive study of autonomous languages. Notwithstanding its normative and policy orientations, language planning as a subfield reflects what Silverstein (2005:2) has termed "the transfer of inductivisms" from nineteenth century comparative philology to twentieth century linguistics, in terms of which autonomy is asserted through association with other deductive sciences - notably botany and geology. This scientific disposition is frequently accompanied by a theoretical commitment to the formal equality of all languages; a commitment usually expressed in terms of abstract potential, rather the actual functions associated with a given language in a given context. A corollary of this disposition is a reluctance to engage with language politics, or to do so in a manner that externalizes the significance of social status in the historical development of languages. And it is this scientific - or rather scientistic - orientation that explains both the entrenchment of language planning as a subfield of structural linguistics as well as the priority that corpus planning tends to enjoy within this subfield. 


\section{Habeas corpus? The search for the body of 'autonomous language'}

'Habeas Corpus' is a legal concept which literally means "have the body". It is a writ issued by a court, which requires that "the body of a person" be brought before the court before the case against the person in question can proceed. The term has both a metaphorical and a literal significance to an analysis of the concepts of 'corpus planning' and 'status planning.' Metaphorically, the problematic interaction between these two concepts in language planning can be likened to the search for a body - the body of autonomous language. Kloss' conceptualization of 'corpus' builds on Saussure's concept of 'langue', or 'language', as an autonomous speech system, abstracted away from its manifestation in actual utterances ('parole') (Saussure 1966). As Love (1989:814) has argued, Saussure's conceptualization of language in this sense freezes "a historically evolving system at an arbitrarily chosen point, to reveal an ahistorical état de langue". Two aspects of this more general critique of structural linguistics have particular relevance to the conceptual problems associated with language planning.

Firstly, the tendency to ignore or underplay the historical significance of writing is evident in the literature on language planning. Thus Haugen's model (cf. Table 1) introduces writing in stage two - codification - and therefore assumes the prior existence of relatively discrete spoken norms, which are available for selection in stage one. Secondly, the attempt to distill policy prescriptions from the history of language standardisation tends to telescope and thereby distort the more recent history of writing as print. The distillation tends to omit specific histories of conflict over symbolic and material resources and - as a result - ignores the historical relationship between language development and social stratification. Corpus planning tends to be seen as a predominantly technical exercise, which excludes the consideration of stratifying processes that give rise to specific language corpora. Particularly significant, in this respect, has been the uneven spread of markets for print and, more specifically, for printed forms or genres. Blommaert (2008:296) notes the role that professional scholars in Africa played in the production of "'inventory' descriptions of language-as-structure", notably "a Grammar, a Dictionary, and a collection of Texts." The monolingual dictionary has more general significance. The monolingual dictionary was not just the Holy Grail of linguistic nationalism; it also provided the model for an autonomous science of language. The concept of 'autonomous language' can be traced back to the emergence of the monolingual dictionary, which provided the prototypical arrangement of form and meaning within a language.

So the supposedly culture-neutral 'science' of spoken language turns out to be founded on the assumption that the way in which a particular close-knit group of literate societies has come to make use of writing, in combination with the linguistic analysis implicit in a device designed to display (for various nonscientific purposes) the verbal resources available to literate members of those societies, already embodies an appropriate conceptualization of its subject matter.

(Love 1989: 805)

The conceptual distinction between 'corpus planning' and 'status planning' therefore has the effect of reducing the former to an objective and a technical subfield within applied linguistics, but leaves the latter in a state of quasi-scientific limbo. ${ }^{28}$ By assuming the prior existence of discrete "language bodies", language planning tends to externalize the problem of status, treating the attribution of status as ancillary to the internal development of a given 
language. Moreover, by defining status principally in terms of function - which is to say in terms of the functions associated with a given language - the literature on language planning has remained largely insulated from sociological debates on the relationship between status and class (Williams 1992:137).

While the term 'status' derives from Latin, referring to standing or position in society, the recent history of the concept is strongly associated with Max Weber's work on social stratification. Weber (in Turner 1988:65-67) argued that industrial societies tend to be stratified as a result of the unequal distribution of three broad categories of power:

(i) Class: income, wealth and other material benefits;

(ii) Status: practices and cultural distinctions associated with "lifestyle";

(iii) Political power: the legal-political entitlements of citizenship.

There are longstanding debates, drawing on the work of Marx and Weber, on (1) the relative significance of class and status in the social stratification of modern societies, and (2) on the extent to which theses concepts should be understood in terms of aggregate (individual) or whole (group) phenomena. Williams (1992:124) notes a tendency in the language planning literature to interchange the concepts of 'prestige' and 'status'. In the United States status tends to be conceptualized as a socio-psychological category, which is to say in terms of the subjective individual "self-perception of prestige" (Turner 1988:4). This tradition therefore tends to privilege a conceptualization of status as subjective disposition, thereby ignoring the more objective dimension of status as positioning within a class structure. The result is a tendency to portray membership of a society - and by extension 'a language' - as essentially consensual. It would therefore seem that, to the extent that the language planning literature has drawn on sociological debates on status, this has come largely by way of a tacit acceptance of Parsonian structural functionalism - a sociological tradition that has tended to conflate status and class and understate the historical significance of social stratification and conflict (Williams 1992:124). The linguistic corollary of this implicit social theory is therefore the tendency to understand status planning as an absolute ${ }^{29}$ and consensual process of building new functions into a given language.

It is with respect to the difficulties associated with the use of the term 'status' in language planning that the reference to habeas corpus has a more literal significance. Bourdieu (1991:49) notes the historical shift in the use of the term 'code' from law to linguistics. He argues that a common language functions as a code in two senses of the word: firstly, by establishing a system of linguistic equivalences between concepts and signifiers and secondly, by establishing a system of norms regulating linguistic practices (Bourdieu 1991:45). The language norms in question - constituting the 'body' - emerge through social conflict and social stratification - processes coextensive with the establishment of equivalent forms and meanings. 'Language' as a group construct (i.e. in references to 'a language' or specific 'languages') must therefore be conceptualized as a status group, whose relative autonomy visà-vis other languages (or rather 'language status groups') is the product of a continuous process of contestation and resource allocation. The difficulty inherent in this reconceptualization derives from the fact that it undermines the belief - cherished by many language professionals - that language planning can be a neutral applied science. To state this is not to deny the existence of specialized technical skills, many of which are transferable between language groups. It does however undermine the belief that language practices can be neatly subdivided into internal and external categories. Discrete languages can only be 
seen in social relief: if this is accepted, then every language practice carries a social cost, and status is the product of social contestation in a context defined by scarce symbolic and material resources.

\section{Conclusion}

In this article I noted how the word 'dialect' was not simply introduced to European languages during the sixteenth century. It rather formed part of a complex process of print-mediated social transformation, through which both 'standard' languages and 'regional dialects' emerged by way of an association with increasingly discrete markets for printed material and the capacity to read. Following the industrial revolution these markets then formed the basis of powerful new political economies, in which the ideologies that underpinned both nationalism and imperial expansion were also instrumental in establishing powerful new 'international' languages. In developing countries - and Africa in particular - the historical association of these languages with colonialism gave rise to demands for the use and development of indigenous languages and - following from this - a market for formal attempts to meet these demands. Language planning - built around a conceptual distinction between internal 'corpus planning' and external 'status planning' - therefore emerged as an applied field of sociolinguistics in the aftermath of decolonisation, when a growing number of sociolinguists sought to distill policy programmes from the history of language standardisation. In this article I have argued that the conceptualisation of 'status' is the weak link in this academic tradition and I conclude with a brief comment on the national policy implications for South Africa.

If status planning is defined as the "effort to regulate the demand for given verbal resources" (Cooper 1990:120), then the central issue that needs to be addressed in the South African context (as elsewhere) is why this has proved to be so difficult. The reason, it would seem, is that language planning is a far more indeterminate and contentious process than most contributions to the language planning literature are prepared to acknowledge. The theoretical issue is not so much whether language planning can be done, but whether it can be done innocently. The idea that it can be done scientifically is premised on the assumption that 'languages' exist as discrete entities and that they can establish a modus vivendi, rather like the individuals who speak them. My critique of this idea is built on a conflict-sociological approach to the study of language, in terms of which status is the product of struggles over the allocation of scarce material and symbolic resources - and these include struggles over the very definition of 'languages'. ${ }^{30}$ Such struggles are manifested in the smallest of practices and not least the technical processes associated with corpus planning. The fragility of the ostensibly neutral process of corpus planning is therefore most evident when claims for dialect demarcation are made above or below the level of officially recognized languages. ${ }^{31}$

We live in an era of growing resource scarcity, in which scholars of resource management (oil, electricity, water etc.) are increasing concerned with demand side management (DSM). To the extent that it is possible for South African writers and policy makers concerned with language policy and planning to move beyond symbolic commitments to multilingualism, a kind of critical linguistic DSM is required. By 'critical' I mean an approach built on a recognition that languages are not natural resources, but rather social artefacts whose relative social value is context-dependent and thereby subject to contestation and management. Whereas corpus-orientated language planning tends to foreground the supply-orientated concerns of language professionals, a more critical approach would focus on a realistic 
assessment of extant and potential demand for new language resources in specific domains or contexts. While this approach seems desirable in principle, it is not obvious how it would work in practice. Given the complexity of actual language change it seems more likely that national language policy will remain predominantly symbolic.

In the context of rapid social and geographical mobility, change is the product of a myriad of social interactions in which choice of language/dialect is asserted, contested or relinquished. The air of consensus that surrounds formal language planning initiatives therefore masks the reality of competing status agendas. In short, the conception of 'language' that underpins much of the contemporary South African literature on language policy has been useful in fostering elite consensus on the need for multilingualism. This consensus is still politically expedient, precisely because it tends to mask the complex nature of language change and the continuing role that languages play in the stratification of post-apartheid society. The irony is that a language policy formulated more explicitly in terms of emerging patterns of social stratification - and one that formally recognizes and acknowledges the complex stratifying role of English - would be better suited to addressing inequality in South Africa.

\section{Notes}

1. This article has had a rather long gestation. I would like to express my appreciation for comments received from two anonymous reviewers. Earlier drafts were presented at the University of Johannesburg in 2009 and at the University of Stellenbosch in 2010. I would also like to thank current and former colleagues at these universities for comments and discussion, notably Simon Bekker, Christiaan Maasdorp and Caroline Jeannerat.

2. "A shprakh iz a dialekt mit an armey un flot" - from a 1945 article in Yiddish.

3. On 16 March 2010 Judge Ben du Plessis ruled that the South African government had, since 2007, failed in terms of the Constitution to regulate and monitor the use of the official languages. He did not however order the government to adopt or legislate a formal language policy. His decision to deliver the verdict in Afrikaans was "motivated by evidence before court that the respondents, in so far as they indeed don't understand Afrikaans, have sufficient translation services" ("High court victory for South African languages", Mail \& Guardian Online, 16 March 2010, available online at http://www. mg.co.za/article/2010-03-16-high-court-victory-for-sa-languages).

4. Constitution of the Republic of South Africa (Act 200 of 1993), chapter 1, section $3(2)$.

5. In terms of section 6(1) of the 1996 Constitution, the official languages of South Africa are Sepedi, Sesotho, Setswana, siSwati, Tshivenda, Xitsonga, Afrikaans, English, isiNdebele, isiXhosa and isiZulu.

6. Constitution of the Republic of South Africa (Act 108 of 1996), chapter 1, section 6(1) and (2).

7. According to the Afrikaans indexing site, Die Knoop (www.dieknoop.co.za), Afrikaans speakers account for about $40 \%$ of disposable income ("besteebare inkomste") in South Africa.

8. See Jones and Grobler, "Runaway circulations for Zulu media while Afrikaans falters", MarketingWeb, 16 February 2007.

9. "Constellation of language movements" would be more accurate. These include the Afrikaanse Taal en Kultuur Vereniging (ATKV), Federasie van Afrikaanse Kultuurvereniginge (FAK) and numerous others. An overarching sense of this 
constellation can be obtained by following the Kultuurgroepe ("cultural groups") and Taaldienste ("language services") links on http://www.soek-afrikaans.co.za/.

10. See Lexicography as a financial asset in a multilingual South Africa, Pretoria: Department of Arts, Culture, Science and Technology, 1996.

11. See Towards a National Language Plan for South Africa - Final report of the Language Plan Task Group (LANGTAG). Pretoria: Department of Arts, Culture, Science and Technology, 1996, p. 11.

12. This was the title of a book (1953) by Uriel Weinreich, the son of Max Weinreich (cited earlier).

13. This was the title of an influential book edited by Fishman, Ferguson and Das Gupta (1968).

14. Fishman's quantitative approach to language planning was stimulated by an analysis of "cross-polity files", i.e. state-level statistical data on minority languages, which were increasingly available during the 1950s and 1960s (Fishman 1968:54).

15. Fishman (1967:34) defines bilingualism as a "characterization of individual linguistic behaviour" and diglossia as a "characterization of linguistic organization at the sociocultural level."

16. In Cooper's (1990) book, which has been influential in South African language policy circles, the chapter on status planning is structured in the form of a list of possible language functions.

17. The influence of these two authors is evident in numerous South African articles (Pieterse 1991; Cluver 1992; Webb 1994; Alexander 1996; Reagan 2002) as well as in the Final Report of the Language Plan Task Group.

18. Between 1450 and 1465, commercial printing presses spread throughout Europe (Febvre and Martin 1984:54).

19. Extracted from William Caxton's "Prologue to Eneydos", reprinted in Bühler (1960).

20. For more detailed accounts of the development of print languages, see Febvre and Martin (1984) and Anderson (1983).

21. These senses are attested in 1579 and 1577 respectively (OED).

22. For a discussion of these two traditions in linguistics, see Mesthrie, Swann, Deumert and Leap (2000:12-15).

23. Williams' (1983:105) reference to the "virtually metaphysical notion of the language as existing in other than its actual variations" is a somewhat ambiguous response to this question.

24. It is noteworthy that the earliest monolingual English dictionary was a list of hard words - Cawdrey's Table Alphabeticall of Hard Wordes - which was published in 1604 and contained about 3000 words. See the Concise Oxford Companion to English Literature, Oxford University Press (2007).

25. The normative ambiguity associated with the term is also evident in the senses attributed to dialek ("dialect") in the Woordeboek van die Afrikaanse Taal (WAT), which in addition to senses equivalent to the OED references cited above, includes "In die omgang minagtend gebruik vir 'n minderwaardige, ontaarde vorm van 'n taal" ("Commonly used in a disparaging sense to refer to an inferior, degenerate form of a language" - my translation).

26. See Mesthrie et al. (2000:51) for a summary of this history.

27. The sense of scale developed with new economies of print. Haugen (1966:924) notes that "dialect" has a particular association with writing in French, where it was frequently used to distinguish new print-standards from unwritten patois. 
28. Williams (1992:136) argues that this false dichotomy "leads to a failure to discuss the inherent relationship between the two issues."

29. Williams (1992:124) argues that "status is a relative and comparative concept and therefore any reference to status planning in language terms must involve reference to more than a single language or language variety."

30. This has been most evident in the debate over the merits of using the name "Sepedi" to refer to "Sesotho sa Lebowa".

31. The issue of African language harmonisation proved to be particularly controversial during the Langtag process. Beukes (2008:16) noted that the "language autonomy issue as far as the African languages were concerned was sidestepped in the Langtag Report."

\section{References}

Alexander, N. 1996. "Language planning from below". BUA! National Language Project.

Alexander, N. 2002. An Ordinary Country - Issues in the Transition from Apartheid to Democracy in South Africa. Pietermaritzburg: University of Natal Press.

Anderson, B. 1983. Imagined Communities - Reflections on the Origin and Spread of Nationalism. London: Verso.

Beukes, A-M. 2008. Language policy implementation in South Africa: How Kempton Park's great expectations are dashed in Tshwane. Stellenbosch Papers in Linguistics 38: 1-26.

Blommaert, J. 1996. Language Planning as a Discourse on Language and Society: The Linguistic Ideology of a Scholarly Tradition. Language Problems and Language Planning 20(3): 199-222.

Blommaert, J. 2008. Artefactual ideologies and the textual production of African languages. Language and Communication 28: 291-307.

Boonzaier, E and J. Sharp (eds). 1988. South African keywords: the uses and abuses of political concepts. Cape Town: David Philip.

Bourdieu, P. 1991. Language and symbolic power. Cambridge: Polity Press.

Bühler, C.F. 1960. William Caxton and his Critics. Syracuse: Syracuse University Press.

Cluver, A.D.deV. 1992. Language Planning Models for a Post-Apartheid South Africa. Language Problems and Language Planning 16(2): 105-136.

Combrink, J. 1991. Die toekomstige status en funksies van Afrikaans. Tydskrif vir Geesteswetenskappe 31(2): 75-92.

Concise Oxford Companion to English Literature. 2007. Oxford: Oxford University Press (online edition).

Cooper, R.L. 1990. Language Planning and Social Change. Cambridge: Cambridge University Press.

Coulmas, F. 1992. Language and Economy. Oxford: Blackwell.

Febvre, L. and Martin, H-J. 1984. The Coming of the Book - The Impact of Printing, 14501800. London: Verso.

Ferguson, C. 1959. Diglossia. Word 15(3): 25-340.

Fishman, J.A. 1967. Bilingualism with and without diglossia; Diglossia with and without bilingualism. Journal of Social Issues 23(2): 29-38.

Fishman, J.A., C.A. Ferguson and J. Das Gupta (eds). 1968. Language problems of developing nations. New York: John Wiley and Sons.

Fishman, J.A. 1968. Sociolinguistics and the language problems of developing countries. In J.A. Fishman, C. Ferguson and J. Das Gupta (eds). Language problems of developing nations. New York: John Wiley and Sons. 
Fishman, J.A. 1989. Status planning for endangered languages. In I. Fodor and C. Hagège (eds). Language Reform, Vol. IV. Hamburg: Helmut Busk Verlag.

Halliday, M.A.K. 2007. Language and Society. New York: Continuum.

Harries, P. 2007. Butterflies \& Barbarians - Swiss Missionaries and Systems of Knowledge in South-East Africa. Oxford: James Curry.

Haugen, E. 1966. Dialect, Language, Nation. American Anthropologist 68(4): 922-935.

Haugen, E. 1983. The implementation of corpus planning: theory and practice. In J. Cobarrubias and J.A. Fishman (eds). Progress in Language Planning: International Perspectives. Berlin: Mouton. pp. 269-289.

Haugen, E. 1997. Language standardization. In N. Coupland and A. Jaworski (eds). Sociolinguistics - A reader and coursebook. New York: St. Martin's Press.

Heugh, K. 2002. Recovering multilingualism: recent language-policy developments. R Mesthrie (ed.) Language in South Africa. Cambridge: Cambridge University Press.

Jones, G. and F. Grobler, "Runaway circulations for Zulu media while Afrikaans falters", MarketingWeb, 16 February 2007.

Kamwangamalu, N.M. 2002. Language policy under scrutiny. Focus 21:1.

Kloss, H. 1969. Research Possibilities on Group Bilingualism: A Report. Quebec: International Centre for Research on Bilingualism.

Lexicography as a financial asset in a multilingual South Africa. 1996. Pretoria: Department of Arts, Culture, Science and Technology.

Love, N. 1989. Transcending Sausure. Poetics Today 10(4): 793-818.

Mesthrie, R., J. Swann; A. Deumert; and W.L. Leap. 2000. Introducing sociolinguistics. Edinburgh: Edinburgh University Press.

Moodley, K. 2000. African Renaissance and language policies in comparative perspective. Politikon 27(1): 103-115.

Mutasa, D. 1999. Language Policy and Language Practice in South Africa: An Uneasy Marriage. Language Matters - Studies in the languages of Southern Africa 30: 83-98.

Oxford English Dictionary (OED). 2010. Oxford: Oxford University Press (online edition).

Pieterse, H.J. 1991. Taalbeplanningsmodelle vir Suid-Afrika: 'n oorsig en voorlopige sintese. Tydskrif vir Geesteswetenskappe 31(2): 87-100.

Reagan, T.G. 2002. Language planning and language policy: past, present and future. In R. Mesthrie (ed.) Language in South Africa. Cambridge: Cambridge University Press.

Ridge, S.G.M. 2001. Is Afrikaans a suitable model in planning the development of African languages? Per Linguam 17(1): 24-35.

Saussure, F. de 1966. Course in General Linguistics. New York: McGraw-Hill.

Shepherd, N. and Robins, S. (eds). 2008. New South African keywords. Johannesburg: Ohio University Press.

Silverstein, M. (2005). Inductivism and the emergence of modern descriptive linguistics. Paper presented at the Xth International Congress on the History of the Language Sciences, Urbana-Champaign, IL, September 2005.

Towards a National Language Plan for South Africa - Final report of the Language Plan Task Group (LANGTAG). 1996. Pretoria: Department of Arts, Culture, Science and Technology.

Turner, B.S. 1988. Status. Milton Keynes: Open University Press.

Webb, V. 1994. Language Policy and Planning in South Africa. Annual Review of Applied Linguistics 14:254-273.

Webb, V. 1995. The technicalization of the autochthonous languages of South Africa: Constraints from a present day perspective. In M. Pütz (ed.) Discrimination through 
Language in Africa? Perspectives from the Namibian Experience. Berlin: Mouton de Gruyter.

Webb, V. 1996b. Language planning and politics in South Africa. International Journal of the Sociology of Language 118:139-162.

Webb, V. 2002. Language in South Africa - The role of language in national transformation, reconstruction and development. Amsterdam: John Benjamins.

Williams, G. 1992. Sociolinguistics: A Sociological Critique. London: Routledge.

Williams, R. 1983. Keywords - A vocabulary of culture and society. London: Fontana Press.

Wright, L. 2000. From planning to practice: Implementation challenges for South Africa's proposed language policy and plan. Per Linguam 16(1): 32-45.

Wright, S. 2004. Language Policy and Language Planning - From Nationalism to Globalisation. New York: Palgrave Macmillan. 